\title{
Microwave irradiation for accelerating the synthesis of acridine and xanthene derivatives from dimedone
}

\author{
El Sayed H. El Ashry ${ }^{*}$, a, Laila F. Awad ${ }^{a}$, El Sayed I. Ibrahim, ${ }^{\text {b }}$ and Omayma Kh. Bdeewy ${ }^{a}$ \\ Chemistry Department, Faculty of Science, ${ }^{a}$ Alexandria University (Alexandria), ${ }^{b}$ Suez Cannel \\ University (Ismalia), Egypt. *Fax: +203-4271360 \\ E-mail: eelashry60@hotmail.com, eelashry60@link.net
}

\begin{abstract}
Microwave (MW) irradiation activated the reaction of dimedone with aniline or p-chloroaniline in formic acid to give the acridine derivatives $\mathbf{2 a}$ and $\mathbf{2} \mathbf{b}$, respectively, which can be derivatized as the bisoximes 3 and bisphenylhydrazone 4 . However, under the same reaction conditions 2aminopyridine gave the xanthene derivative $\mathbf{6}$ and not the expected acridine derivative 2c. When 2-aminopyridine was allowed to react under MW irradiation with dimedone in presence of benzaldehyde in ethanol it gave the bis(dimedonyl)methane derivative 10. Cyclization of $\mathbf{1 0}$ has been enhanced under MW irradiation to give the xanthene derivative $\mathbf{9}$ in improved yield and in less time than the conventional heating. The structures of products were confirmed from the analysis of their IR, ${ }^{1} \mathrm{H}-\mathrm{NMR}$ and mass spectra. The antimicrobial activity has been investigated for compounds 3, 4, 6 and 10.
\end{abstract}

Keywords: Dimedone, acridine, xanthene, microwave

\section{Introduction}

Chemical and pharmaceutical industries are facing constraints regarding the environmental aspects and saving energy. A major concern to overcome such problems in organic synthesis has considered the use of microwave (MW) irradiation as a source of energy. This led to a dramatic increase of the number of publications using MW in organic synthesis ${ }^{1,2}$. Recently, we became interested in using MW for accelerating organic reactions whereby varied numbers of heterocycles and carbohydrates has been achieved ${ }^{1-3}$.

Acridine derivatives have a wide spectrum of biological activities as antibacterial, antimalarial, anticancer and mutagenic properties, principally connected with their ability to inhibit the enzymes acting on nucleic acids ${ }^{4}$. Our protocol was designed for a comparative study for constructing some acridine and xanthene derivatives from dimedone under the influence of 
MW and conventional methods as a continuation of our interest in the utilization of dimedone as precursor for heterocyclic compounds ${ }^{5}$.

\section{Results and Discussion}

A one step reaction of dimedone (1) with aniline or $p$-chloroaniline in formic acid to give the 10aryl-decahydroacridine derivatives ${ }^{6} \mathbf{2 a , b}$ required heating at $150{ }^{\circ} \mathrm{C}$ for 23 hours. We found that this cyclocondensation can be conveniently achieved within 12 minutes using a solvent-free condition under MW irradiation. Less amount of formic acid was used which was repoted to have a methylenating role $e^{6,7}$ of $\mathbf{1}$ whose subsequent cyclization gave acridines 2 . The structures of the acridine derivatives $\mathbf{2 a - b}$ were confirmed from their ${ }^{1} \mathrm{H}-\mathrm{NMR}$ spectra; that of $\mathbf{2} \mathbf{b}$ showed the presence of four equivalent methyl groups resonating as a singlet at $\delta 0.87$, whereas the methylene protons at C-2 and C-7 as well as C-4 and C-5 appeared as two singlets at $\delta 1.83$ and 2.17 , respectively. The $\mathrm{C}-9$ methylene protons resonated as a singlet at a higher frequency region at $\delta$ 2.97. The two doublets at $\delta 7.42$ and 7.62 confirmed the presence of the aromatic protons.

The presence of the two carbonyl groups in $\mathbf{2} \mathbf{a}$ and $\mathbf{2} \mathbf{b}$ were confirmed by the condensation with hydroxylamine under conventional heating for 3-5 hours to afford the 1,8-dioxime derivatives 3a,b in 56 and $50 \%$ yield, respectively, whereas under MW irradiation they were obtained within 3 minutes in much better yields; 79 and $90 \%$ yield, respectively. Moreover, condensation of $\mathbf{2 b}$ with phenylhydrazine gave the respective bisphenylhydrazone 4 in $57 \%$ yield upon boiling in ethanol for 2 hours, and in $64 \%$ yield under MW irradiation for 3 minutes. The structures of $\mathbf{3 a}, \mathbf{b}$ and $\mathbf{4}$ were established from their spectral data.

When 2-aminopyridine was used, instead of the arylamines, in the reaction with dimedone (1) in presence of formic acid, a crystalline product was obtained whose spectral and elemental analysis were inconsistent with the acridine derivatives 2c, but agreed with the structure 6 . Attempted use of MW irradiation to direct the above reaction to give 2c, led also to $\mathbf{6}$ but within one minute instead of 30 minutes under the conventional heating. Fast atom bombardment mass spectrum (FABMS) of the product showed a peak at $\mathrm{m} / \mathrm{z} 413$ due to a protonated molecular ion peak which agreed with the molecular formula $\mathrm{C}_{25} \mathrm{H}_{32} \mathrm{O}_{5}$. The ${ }^{1} \mathrm{H}-\mathrm{NMR}$ spectrum of 6 exhibited three singlets at the lower frequency region at $\delta 0.97,1.00$ and 1.10 corresponding to the protons of six methyl groups indicating that three dimedone units were present in 6. Moreover, their six methylene protons were also deduced from the singlets at $\delta 2.02,2.26,2.34,2.42$ and 2.48. Furthermore, no signals corresponding to the pyridyl moiety were found at the higher frequency region. Based on these data the product have been assigned the structure 9-(5,5-dimethyl-3-oxocyclohex-1-en-1-ol-2-yl)-2,3,4,5,6,7-hexahydroxanthene-1,8-dione (6). Further confirmation for the structure was obtained from its identity with the product resulting from the condensation of dimedone (1) with 2-formyldimedone (5) $)^{8,9}$ or triethyl orthoformate ${ }^{10}$.

The formation of $\mathbf{6}$ can be explained by the formylation of $\mathbf{1}$ to give the 2-formyldimedone 5 as intermediate which was further condensed with two molecules of dimedone and 
subsequently cyclized to give 6. It seems that the basic properties of 2-aminopyridine played a role on catalyzing both formylation and its condensation with 1 rather than its involvement in the reaction to form 2c (Scheme 1).<smiles>CC1(C)CC(=O)CC(=O)C1</smiles>

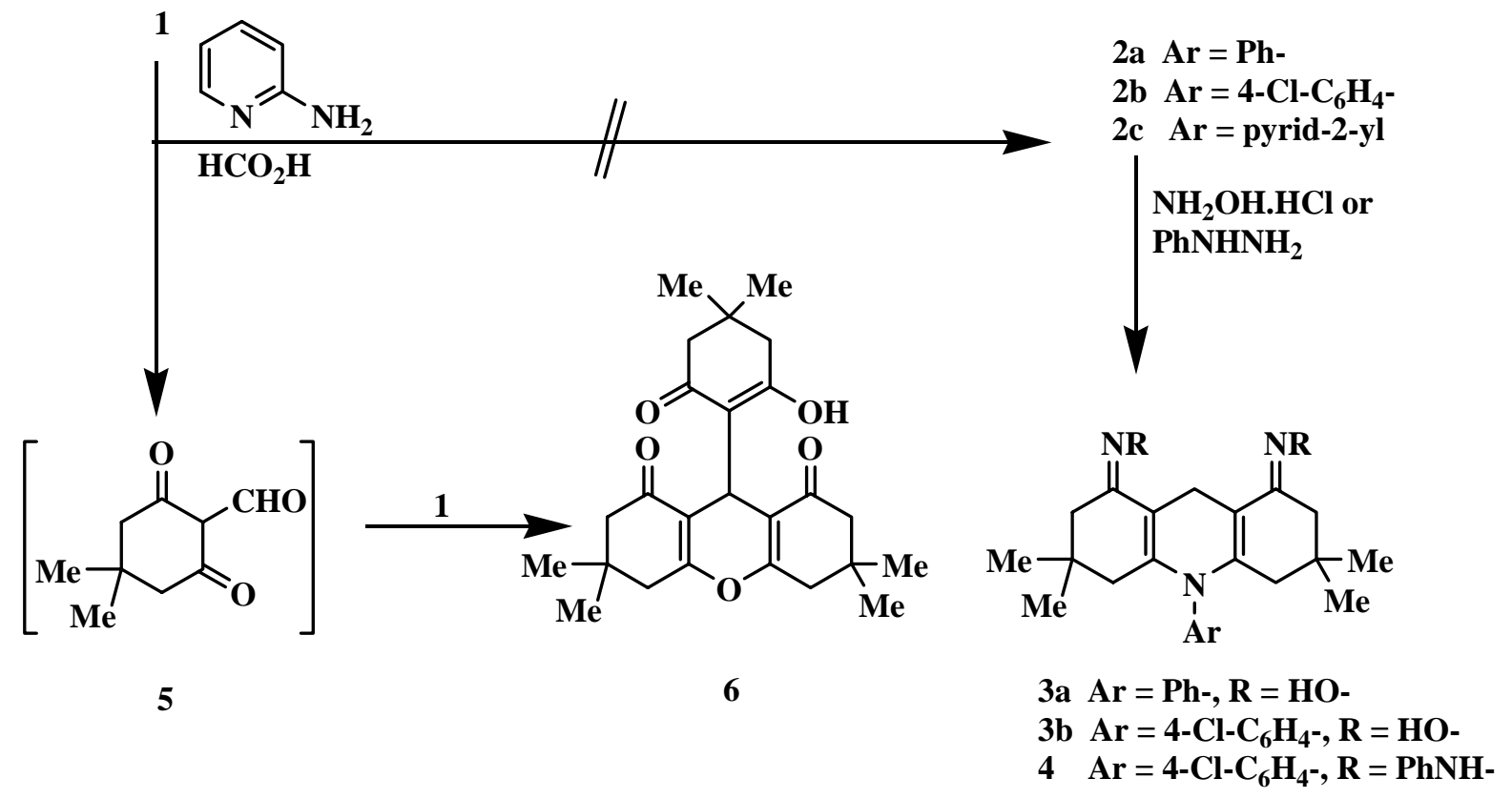

\section{Scheme 1}

Various fused heterocyclic compounds containing the dihydropyridine moiety were conventionally synthesized by the cyclocondensation of $\mathbf{1}$ with aminoheterocycles and aromatic aldehydes $^{11-16}$. Such approach looks attractive for the synthesis of fused partially hydrogenated pyridoquinoline derivative such as 7 . However, under the same reaction conditions, boiling equimolar amounts of dimedone (1), 2-aminopyridine and benzaldehyde in absolute ethanol, neither the pyridoquinoline derivative $\mathbf{7}$ nor the acridine derivative $\mathbf{8}$ were formed. The elemental analysis of the isolated product indicated the absence of nitrogen, and agreed with the molecular formula $\mathrm{C}_{23} \mathrm{H}_{28} \mathrm{O}_{4}$. Its ${ }^{1} \mathrm{H}$ NMR spectrum showed the presence of five protons in the aromatic region indicating the presence of a phenyl group and the absence of a pyridine moiety. The presence of four methyl groups, resonated as two singlets a $\delta 0.98$ and 1.17, and four methylene protons at $\delta 2.39-2.48$ were consistent with the presence of two dimedone units. A signal for the enolic $\mathrm{OH}$ proton was observed at $\delta 11.92$ and a singlet for the $\mathrm{CHPh}$ appeared at $\delta$ 5.54. Accordingly, the isolated product was assigned the structure 10. It was readily confirmed 
by its conversion to 3,3,6,6-tetramethyl-9-phenyl-octahydro-xanthene-1,8-dione ${ }^{17}$ (11) by boiling with dilute hydrochloric acid in ethanol.

The formation of the bis(dimedonyl)methane derivative $\mathbf{1 0}$ may have taken place either through formation of the Schiff's base 13, whose $\mathrm{C}=\mathrm{N}$ has spontaneously added dimedone (1) to form the adduct 12. Subsequent elimination of the 2-aminopyridine moiety, rather than cyclization to the pyridoquinoline 7 , afforded the intermediate 9 which upon reaction with dimedone gave 10; such mode of reaction has been noted in the reaction of dimedone with some arylideneanilines ${ }^{18-20}$. Further support for this rationale can be drawn from the elimintation of the 5-aminopyrazole moiety from the product of addition of its benzylidene derivatives to ethyl cyanoacetate $^{21}$; the donor/acceptor effect of substituents on the benzylidene moiety influences to a significant extent the reactivity of the azomethine carbon ${ }^{19}$. Alternatively, the $1: 1$ adduct 9 may be formed as a key step in the condensation of dimedone and benzaldehyde, followed by subsequent Michael addition of another molecule of dimedone. Attempted synthesis of 9 by microwave irradiation of equimolar amount of dimedone and benzaldehyde in acetic anhydride in the presence of catalytic amount of sodium acetate afforded $\mathbf{1 0}$ rather than 9; a spontaneous reaction of the presumably formed 9 with dimedone has taken place to give 10. Although such condensation was described in the literature ${ }^{20}$, it is unsuccessful for all aldehydes ${ }^{21}$ (Scheme 2).

The above results indicated that in contrary to other amino heterocyclic compounds, 2aminopyridine did not react, in a similar manner, with dimedone to give the pyridoquinoline analogue. Moreover, the use of $\mathrm{MW}$ in performing the above reactions provided similar pathways to the conventional heating, but in much reduced times and better yields.

The antimicrobial activity against Staphylococcus aureus, Candida albicans, Escherichia coli and Psudominus aureus for compounds 3a,b, 4, $\mathbf{6}$ and $\mathbf{1 0}$ was evaluated by agar diffusion technique using Ampicilin and Chlotrimazole as references (Table 1).

Although the oxime derivative 3a showed a lower activity (IZ 22) against Staphlococcus aureus, the 10-p-chlorophenyl derivative $\mathbf{3 b}$ exhibited no activity. However, both compounds showed a lower inhibition (IZ 16) relative to Chlotrimazole against Candida albicans. The bishydrazone 4 showed lower activity compared to ampicilin (IZ 23) against Staphylococcus aureus and it exhibits a compatible inhibition (IZ 22) relative to Chlotrimazole. On the other hand, the xanthene derivative 6 showed that it possess a potential antimicrobial activity (IZ 34 and 28) relative to ampicilin (IZ 35) and Chlotrimazole (IZ 23), respectively against Staphlococcus aureus and Candida albicans, respectively. However, the uncyclized product 10 showed a lower inhibition activities. None of the tested compounds showed inhibition activity against Escherichia coli and Psudominus aureus. 

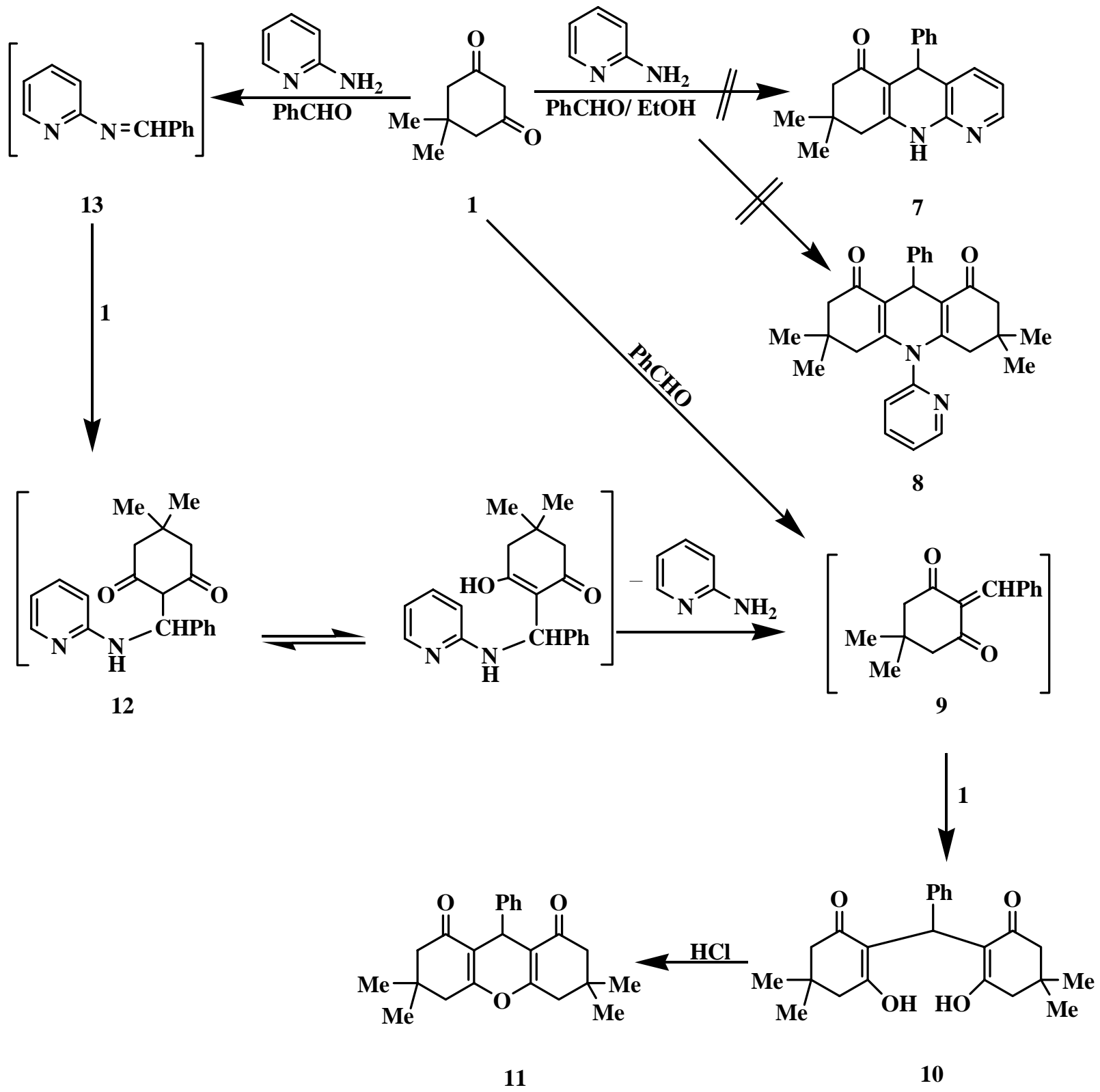

Scheme 2 
Table 1. The antimicrobial activity of selected compounds

\begin{tabular}{ccccc}
\hline $\begin{array}{c}\text { Inhibition zone (IZ) } \\
\text { Compd. No }\end{array}$ & S. aureus & C. albicans & E. coli & Ps. Aureus \\
\hline 3a & 22 & 16 & - & - \\
3b & - & 16 & - & - \\
$\mathbf{4}$ & 23 & 22 & - & - \\
$\mathbf{6}$ & 34 & 28 & - & - \\
$\mathbf{1 0}$ & 18 & 15 & - & - \\
Ampicilin & 35 & - & 11 & - \\
Chlotrimazole & - & 23 & - & - \\
\hline
\end{tabular}

In conclusion MW irradiation activated the reaction of dimedone with aromatic amines in formic acid to give the acridine derivatives. However, under the same reaction conditions 2aminopyridine gave a xanthene derivative containing three dimedonyl moities and not the expected acridine derivative. When 2-aminopyridine was allowed to react under MW irradiation with dimedone in presence of benzaldehyde in ethanol it gave the bis(dimedonyl)methane derivative. The MW has improved the yields in less time than the conventional heating.

\section{Experimental Section}

General Procedures. M.p.'s were determined with a Mel-Temp apparatus and are uncorrected. TLC was performed on Baker-Flex silica gel 1B-F $(1.55 \mathrm{~cm})$ plates, and the spots were detected by UV light absorption. IR spectra were recorded in matrix of $\mathrm{KBr}$ with Perkin-Elmer 1430 spectrometer. ${ }^{1} \mathrm{H}$ NMR spectra were recorded on Jeol spectrometer $(500 \mathrm{MHz})$ and Bruker AC $(300 \mathrm{MHz})$ spectrometer and the chemical shifts $(\delta)$ are given in ppm relative to the signal for TMS as internal standard. Mass spectra were recorded using electron ionization (EI) on a finnigan MAT 312 spectrometer and fast-atom-bombardment (FAB) on a kratos MS50 spectrometer. Microwave irradiation was done in a domestic microwave oven EM-230M (800 watt output power). The microanalyses were performed in the unit of microanalysis at Faculty of Science, Cairo University.

10-Aryl-3,3,6,6-tetramethyl-1,2,3,4,5,6,7,8,9,10-decahydroacridine-1,8-dione

(2a,b).

General method A. A mixture of dimedone $(10 \mathrm{mmol})$ and aniline or p-chloroaniline (10 $\mathrm{mmol})$ in $98 \%$ formic acid $(20 \mathrm{ml})$ was heated at $150{ }^{\circ} \mathrm{C}$ for $23 \mathrm{hr}$. The reaction mixture was poured onto ice water. The product was filtered off, washed with water and recrystallized from ethanol to give 2a,b.

General method B. A mixture of dimedone $(1.5 \mathrm{mmol})$ and aniline or p-chloroaniline $(1.5$ $\mathrm{mmol})$ in $98 \%$ formic acid $(0.2 \mathrm{ml})$ was irradiated in Teflon screw capped vessel by microwaves for $12 \mathrm{~min}$. The reaction mixture was then processed as in method a. 
10-Phenyl-3,3,6,6-tetramethyl-1,2,3,4,5,6,7,8,9,10-decahydroacridine-1,8-dione (2a). Yellow crystals, obtained in $40 \%$ yield from method a and in $53 \%$ yield from method b; mp 254-256 ${ }^{\circ} \mathrm{C}$; 1 it ${ }^{6} \mathrm{mp} 258-260{ }^{\circ} \mathrm{C}$.

10-(4-Chlorophenyl)-3,3,6,6-tetramethyl-1,2,3,4,5,6,7,8,9,10-decahydroacridine-1,8-dione (2b). Pale yellow crystals, obtained in $42 \%$ yield from method a and $50 \%$ yield from method b; mp 253-255 ${ }^{\circ} \mathrm{C}$, IR (KBr) $1636 \mathrm{~cm}^{-1}(\mathrm{C}=\mathrm{O}) ;{ }^{1} \mathrm{H}$ NMR (DMSO- $\left.d_{6}, 500 \mathrm{MHz}\right), \delta_{\mathrm{H}}: 0.87(\mathrm{~s}, 12$ $\mathrm{H}, 4 \mathrm{Me}), 1.83\left(\mathrm{~s}, 4 \mathrm{H}, 2 \mathrm{CH}_{2}\right), 2.14\left(\mathrm{~s}, 4 \mathrm{H}, 2 \mathrm{CH}_{2}\right), 2.97\left(\mathrm{~s}, 2 \mathrm{H}, \mathrm{CH}_{2}\right), 7.42(\mathrm{~d}, 2 \mathrm{H}, \mathrm{J} 8.6 \mathrm{~Hz}$, Ar-H), 7.62 (d, 2 H, J 8.6 Hz, Ar-H). Anal. Calc. For: $\mathrm{C}_{23} \mathrm{H}_{26} \mathrm{NO}_{2} \mathrm{Cl}$ : C, 71.95; H, 6.83; N, 3.65. Found: C, 71.95; H, 7.82; N, 3.64\%.

10-Aryl-3,3,6,6-tetramethyl-1,2,3,4,5,6,7,8,9,10-decahydroacridine-1,8-dioxime

(3a,b).

General method A. A solution of compounds $2 \mathbf{a}$ or $\mathbf{2 b}(5 \mathrm{mmol})$ in ethanol $(30 \mathrm{ml})$ was treated with hydroxylamine hydrochloride $(24 \mathrm{mmol})$ and sodium acetate $(24 \mathrm{mmol})$. The reaction mixture was boiled under reflux for 3-5 hr. It was left to cool and the product was filtered off and recrystallized from methanol and dimethylformamide mixture to give 3a,b.

General method B. A mixture of compound $2 \mathrm{a}$ or $2 \mathrm{~b}(0.25 \mathrm{mmol})$, hydroxylamine hydrochloride $(1.2 \mathrm{mmol})$ and sodium acetate $(2 \mathrm{mmol})$ in ethanol $(1 \mathrm{ml})$ was irradiated for 3 minutes. The reaction was then processed as in method a.

3,3,6,6-Tetramethyl-10-phenyl-1,2,3,4,5,6,7,8,9,10-decahydroacridine-1,8-dioxime (3a). Pale yellow crystals, $56 \%$ yield from method a and $79 \%$ yield from method b; mp $220-222{ }^{\circ} \mathrm{C}$; IR (KBr) $1642 \mathrm{~cm}^{-1}(\mathrm{C}=\mathrm{N}) ;{ }^{1} \mathrm{H}$ NMR (DMSO-d $\left.6,500 \mathrm{MHz}\right), \delta_{\mathrm{H}}: 0.85$ (s, $\left.12 \mathrm{H}, 4 \mathrm{Me}\right), 1.82$ (s, $4 \mathrm{H}$, $2 \mathrm{CH}_{2}$ ), 2.14 (s, $4 \mathrm{H}, 2 \mathrm{CH}_{2}$ ), 2.99 (s, $2 \mathrm{H}, \mathrm{CH}_{2}$ ), 7.51 (d, $\left.2 \mathrm{H}, \mathrm{Ar}-\mathrm{H}\right)$, 7.52-7.55 (m, $\left.3 \mathrm{H}, \mathrm{Ar}-\mathrm{H}\right)$, $10.70(\mathrm{~s}, 2 \mathrm{H}, 2 \mathrm{OH})$. Anal. Calc for $\mathrm{C}_{23} \mathrm{H}_{29} \mathrm{~N}_{3} \mathrm{O}_{2}$ : C 72.79; $\mathrm{H}$ 7.70; $\mathrm{N}$ 11.07. Found: $\mathrm{C}$ 72.63; H 7.56; N $11.36 \%$.

10-(4-Chlorophenyl)-3,3,6,6-tetramethyl-1,2,3,4,5,6,7,8,9,10-decahydroacridine-1,8-dioxime (3b). Yellow crystals, $50 \%$ yield from method a and $90 \%$ yield from method $\mathbf{b} ; \mathrm{mp} 236-238^{\circ} \mathrm{C}$; IR (KBr) $3209(\mathrm{OH}), 1645(\mathrm{C}=\mathrm{N}) \mathrm{cm}^{-1} .{ }^{1} \mathrm{H}$ NMR (DMSO-d $\left.6,500 \mathrm{MHz}\right), \delta_{\mathrm{H}}: 0.78(\mathrm{~s}, 6 \mathrm{H}, 2$ $\mathrm{Me}), 0.83(\mathrm{~s}, 6 \mathrm{H}, 2 \mathrm{Me}), 1.55\left(\mathrm{~s}, 2 \mathrm{H}, \mathrm{CH}_{2}\right), 1.80\left(\mathrm{~s}, 2 \mathrm{H}, \mathrm{CH}_{2}\right), 2.08\left(\mathrm{~s}, 2 \mathrm{H}, \mathrm{CH}_{2}\right), 2.23(\mathrm{~s}, 2 \mathrm{H}$, $\left.\mathrm{CH}_{2}\right), 3.00$ (s, $\left.2 \mathrm{H}, \mathrm{CH}_{2}\right), 7.31$ (d, $\left.2 \mathrm{H}, \mathrm{Ar}-\mathrm{H}\right), 7.54$ (d, $\left.2 \mathrm{H}, \mathrm{Ar}-\mathrm{H}\right), 10.67$ (s, $\left.2 \mathrm{H}, 2 \mathrm{OH}\right)$. Anal. Calc for $\mathrm{C}_{23} \mathrm{H}_{28} \mathrm{~N}_{3} \mathrm{O}_{2} \mathrm{Cl}$ : C 66.73; $\mathrm{H}$ 6.82; N 10.15. Found: $\mathrm{C} 66.91 ; \mathrm{H} 6.93 ; \mathrm{N} \mathrm{10.45 \% .}$ 10-(4-Chlorophenyl)-3,3,6,6-tetramethyl-1,2,3,4,5,6,7,8,9,10-decahydroacridine-1,8bis(phenyl- hydrazone) (4). Method A. A solution of compound $2 \mathbf{b}$ (1.9 g, $5 \mathrm{mmol})$ in ethanol $(50 \mathrm{ml})$ was treated with phenylhydrazine $(10 \mathrm{mmol})$ and two drops of acetic acid. The reaction mixture was heated under reflux for $2 \mathrm{hr}$. and then cooled. The product was recrystallized from methanol (57\% yield); mp 203-204 ${ }^{\circ} \mathrm{C}$; IR (KBr) $3360(\mathrm{NH}), 1601 \mathrm{~cm}^{-1}(\mathrm{C}=\mathrm{N}),{ }^{1} \mathrm{H}$ NMR (DMSO-d $6,500 \mathrm{MHz}), \delta_{\mathrm{H}}: 1.03(\mathrm{~s}, 12 \mathrm{H}, 4 \mathrm{Me}), 2.46\left(\mathrm{~s}, 4 \mathrm{H}, 2 \mathrm{CH}_{2}\right), 2.61\left(\mathrm{~s}, 4 \mathrm{H}, 2 \mathrm{CH}_{2}\right), 3.38$ (s, 2 H, CH ), 6.93 (t, 2 H, J 7.5 Hz, Ar-H), 7.35-7.41 (m, 8 H, Ar-H), 7.68 (d, 2 H, J 8.6 Hz, Ar$\mathrm{H}), 7.96(\mathrm{~d}, 2 \mathrm{H}, 8.6 \mathrm{~Hz}, \mathrm{Ar}-\mathrm{H}), 9.81(\mathrm{~s}, 1 \mathrm{H}, \mathrm{NH}), 10.13(\mathrm{~s}, 1 \mathrm{H}, \mathrm{NH})$. Anal. Calc for $\mathrm{C}_{35} \mathrm{H}_{38} \mathrm{~N}_{5} \mathrm{Cl}$ : C 74.51; H 6.79; N 12.42. Found: C 74.23; H 6.98; N 12.09\%.

Method B. A mixture of compound $2 \mathbf{b}(0.1 \mathrm{~g}, 0.26 \mathrm{mmol})$, phenylhydrazine $(0.4 \mathrm{mmol})$ and two drops of acetic acid in ethanol was irradiated under MW irradiation for 3 mins. The product 4 was obtained in $64 \%$ yield; identical with the product from method a. 
9-(5,5-Dimethyl-3-oxo-cyclohex-1-en-1-ol-2-yl)-3,3,6,6-tetramethyl-1,2,3,4,5,6,7,8-

octahydro- xanthene-1,8-dione (6). A mixture of dimedone 1 (1.4 g, $10 \mathrm{mmol})$ and 2aminopyridine $(0.9 \mathrm{~g}, 10 \mathrm{mmol})$ in $98 \%$ formic acid $(20 \mathrm{ml})$ was heated under reflux for $30 \mathrm{~min}$. The reaction mixture was then evaporated under reduced pressure. The residue was stirred in water and the product was filtered, washed with warm water and then recrystallized from ethanol. It was obtained as colorless crystals ( $0.7 \mathrm{~g}, 51 \%$ yield $)$; mp $224{ }^{\circ} \mathrm{C}$; 1 lit $^{8} \mathrm{mp} 223-226{ }^{\circ} \mathrm{C}$; ${ }^{1} \mathrm{H}$ NMR $\left(\mathrm{CDCl}_{3}, 300 \mathrm{MHz}\right), \delta_{\mathrm{H}}: 0.97,1.00(2 \mathrm{~s}, 12 \mathrm{H}, 4 \mathrm{Me}), 1.10$ (s, $\left.6 \mathrm{H}, 2 \mathrm{Me}\right), 2.02(\mathrm{~s}, 2 \mathrm{H}$, $\mathrm{CH}_{2}$ ), 2.26 (s, $4 \mathrm{H}, 2 \mathrm{CH}_{2}$ ), 2.34, 2.42, 2.48 (3 s, $\left.6 \mathrm{H}, 3 \mathrm{CH}_{2}\right), 4.32$ (s, $\left.1 \mathrm{H}, \mathrm{CH}-9\right), 9.90$ (bs, $1 \mathrm{H}$, $\mathrm{OH}) ; \mathrm{FABMS}, \mathrm{m} / \mathrm{z} 413\left(\mathrm{M}^{+\cdot}+1,11 \%\right)$.

Bis(4,4-dimethyl-2,6-dioxo-cyclohexen-2-yl)phenylmethane (10). Method A. A mixture of dimedone (2.8 g, $20 \mathrm{mmol})$, 2-aminopyridine (1.84 g, $20 \mathrm{mmol})$ and benzaldehyde $(2.1 \mathrm{ml}, 20$ $\mathrm{mml})$ in absolute ethanol $(20 \mathrm{ml})$ was boiled under reflux for $30 \mathrm{~min}$. The reaction mixture was evaporated under reduced pressure. The resulting syrup was washed with petroleum ether until all unreacted benzaldehyde was removed. The product was recrystallized from absolute ethanol to give 10 as colorless crystals ( $1.5 \mathrm{~g}, 43 \%$ yield); mp 198-200 ${ }^{\circ} \mathrm{C}$, $1 \mathrm{lit}^{22} \mathrm{mp} 195{ }^{\circ} \mathrm{C} ;{ }^{1} \mathrm{H} \mathrm{NMR}$ $\left(\mathrm{CDCl}_{3}, 500 \mathrm{MHz}\right), \delta_{\mathrm{H}}: 0.98,1.17(2 \mathrm{~s}, 12 \mathrm{H}, 4 \mathrm{Me}), 2.39-2.44\left(\mathrm{~m}, 8 \mathrm{H}, 4 \mathrm{CH}_{2}\right), 5.54(\mathrm{~s}, 1 \mathrm{H}$, $\mathrm{CH}), 7.11$ (d, 2 H, J 8.4 Hz, Ar-H), 7.16 (t, 1 H, Ar-H), 7.26 (t, 2 H, Ar-H), 11.92 (s, 1 H, OH).

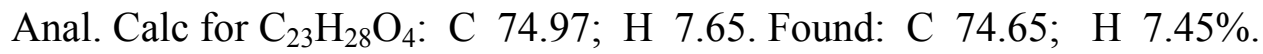

Method B. A mixture of benzaldehyde $(0.15 \mathrm{ml}, 1.4 \mathrm{mmol})$, dimedone $(0.2 \mathrm{~g}, 1.4 \mathrm{mmol})$, acetic anhydride $(1.0 \mathrm{ml})$ and sodium acetate $(0.1 \mathrm{~g}, 1.9 \mathrm{mmol})$ was irradiated in a microwave oven for 5 min. The product was recrystallized from absolute ethanol to give $\mathbf{1 0}$ as colorless crystals ( $0.27 \mathrm{~g}, 50 \%$ yield).

3,3,6,6-Tetramethyl-9-phenyl-1,2,3,4,5,6,7,8-octahydro-xanthene-1,8-dione (11). A solution of $10(0.1 \mathrm{~g}, 0.14 \mathrm{mmol})$ in ethanol $(5 \mathrm{ml})$ and $\mathrm{HCl}(1.0 \mathrm{ml})$ was heated under reflux for $1 \mathrm{hr}$ and then left to cool. The product was recrystalized from ethanol as colorless crystals $(0.07 \mathrm{~g}, 70 \%$ yield), mp $203^{\circ} \mathrm{Clit}^{17,22} \mathrm{mp} 200^{\circ} \mathrm{C}$.

\section{References}

1. Gedye, R. N.; Smith, F. E.; Westaway, K. C.; Ali, H.; Baldisera, L.; Laberge, L.; Rousell, J. Tetrahedron Lett. 1986, 27, 279. (b) Gigere, R. J.; Bray, T. L.; Duncan, S. M.; Majetich, J. Tetrahedron Lett. 1986, 27, 4945. (c) Perreux, L.; Loupy, A. Tetrahedron 2001, 57, 9199. (d) Baghurst, D. R.; Mingos, D. M. P. J. Chem. Soc. Chem. Commun. 1988, 829.

2. Hamelin, J.; Bazureau, J. P.; Texier-Boullet, F. In Microwave in Organic Synthesis; Louby, A.; Ed; Wiley-VCH: Weinheim, 2002; p 253.

3. Abdel-Rahman, A. A. H.; El Ashry, E. S. H. Synlett 2002, 12, 2023. (b) Abdel Hamid, H. M.; Ramadan, E.; Hagar, M.; El Ashry, E. S. H. Synth._Commun. 2004, 34, 377. (b) El Ashry, E. S. H.; Ramadan, E.; Abdel Hamid, H. M.; Hagar, M. Synlett 2004, 723. (c) El Ashry, E. S. H.; Ramadan, E.; Abdel Hamid, H. M.; Hagar, M. Lett. Org. Chem. 2005, 2, 415. (d) El Ashry, E. S. H.; Ramadan, E.; Abdel Hamid, H. M.; Hagar, M. J. Chem. Res. 
2005, 229. (e) El Ashry, E. S. H.; Ramadan, E.; Abdel Hamid, H. M.; Hagar, M. Synth.

Commun. 2005, 35, 1. (f) El Ashry, E. S. H.; Ramadan, E.; Kassem, A. A.; Hagar, M. Adv. Heterocycl. Chem. 2005, 88, 1. (g) El Ashry, E. S. H.; Kassem, A. A. Akivoc, 2006, (ix), 1. (h) El Ashry, E. S. H.; Kassem, A. A.; Ramadan, E. Adv. Heterocycl. Chem. 2005, 90, in press.

4. Peacocke, A. R.; Nicholson, B. H.; Dean, A. C. R.; Clayson, D. B.; Henry, D. W. Heterocycl. Compd., Acheson, R. M., Ed. John Wiley: New York, 1973,Vol. 9, p 723.

5. El Ashry, E. S. H.; Labib, G. H.; Shaban, M. A. E.; El Sayed, F. Indian J. Chem. 1978, 16B, 871. (b) Rashed, N.; Sayed, M.; El Ashry, E. S. H. J. Chinese Chem. Soc. 1993, 40, 189. (c) Abdel Hamid, H.; Mousaad, A.; Sayed, M.; El Ashry, E. S. H. Org. Prep. Proc. Intl. 1993, 25, 596. (d) Rashed, N.; El Ashry, E. S. H. Alex. J. Pharm. Sci. 1993, 7, 137.

6. Bakibaev, A. A. Russ. J. Org. Chem. 1994, 30, 1109.

7. Bakibaev, A. A.; Filimonov, V. D. Zh. Org. Chem. 1991, 27, 854.

8. Akehurst, B. D.; Bartels-Keith, J. R. J. Chem. Soc. 1957, 4798.

9. Vorlander and Guthke Ber. 1929, 62, 549.

10. Wolfbeis, O. S.; Junek, H. Tetrahedron Lett. 1973, 4905.

11. Quiroga, J.; Hormaza, A.; Insuasty, B.; Ortiz, A. J.; Sanchez, A.; Nogueras, M.; J. Heterocycl. Chem. 1998, 35, 231.

12. Quiroga, J.; Insuasty, B.; Hormaza, A.; Saitz, C.; Jullian, C. J. Heterocycl. Chem. 1998, 35, 575.

13. Quiroga, J.; Hormoza, A.; Insuasty, B.; Nogueras, M.; Sanchez, A.; Hanold, N.; Meier, H. J. Heterocycl. Chem. 1997, 34, 521.

14. Quiroga, J.; Insuasty, B.; Sanchez, A.; Nogueras, M.; Meier, H. J. Heterocycl. Chem. 1992, 29, 1045.

15. Quiroga, J.; Insuasty, B.; Pungo, M.; Mendoza, L.; Meier, H. An. Quim. 1994, 90, 300.

16. Oriov, V. D.; Quiroga, J.; Kolos, N. N. Khim. Geterotsikl. Soedin. 1987, 9, 1247.

17. Vanag, G. Ya.; Stankevich, E. N. Zh. Obshch. Khim. 1960, 30, 3287.

18. Kozlov, N. G.; Gusak, K. N.; Makhnach, S. A. Chem. Heterocycl. Compd. 1996, 32, 30.

19. Hennig, L.; Alva-Astudillo, M.; Mann, G.; Kappe, T. Monatsh. Chem. 1992, 123, 571.

20. Kozov, N. S.; Nugumanov, Z. Z. Vestsi Akad. Navuk. Belors. SSR, Ser. Khim. Navuk 1968, 67; Chem. Abstr: 1969, 71, 3240. (b) Horning, E.; Horning, M. G.; J. Org. Chem. 1946, 11, 95. (c) Sleziak, R.; Balaziova, S.; Krutosikova, A. Collect. Czech. Chem. Commun. 1999, 64, 1135.

21. Hennig, L.; Alva-Astudillo, M.; Meusinger, R.; Mann, G. Monatsh. Chem. 1993, 124, 893. (b) Thull, U.; Testa, B. Biochem. Pharmacol. 1994, 47, 2307. (c) Manbi, Y.; Regely, K.; Oesovszky, I.; Barbe, J.; Galy, J. P.; Malnov, J. Anticancer Res. 1994, 14, 2633.

22. Vogel, A. I. Practical Organic Chemistry, Longmans: UK, 1967. 